\title{
A New Peptide Synthesis
}

Cook, Heilbron and Levy ${ }^{1}$ have recently prepared tetraglycylglycine and several di-peptides by reaction of 2-thio-5-thiazolones with amino-acid derivatives. During the past few years, much interest has also been shown in the polymerization potentialities of the $N$-carboxy anhydrides of $\alpha$-amino-acids ${ }^{2-5}$. Study of the reaction of these anhydrides with simple organic bases has now indicated the mechanism of their polymerization and provided a new method of building up polypeptides by addition of single amino-acid units.

The new $\mathrm{N}: \mathrm{N}$-dicarboxy di-anhydride (I) of L-cystine, which was prepared as a crystalline molecular compound with dioxan, undergoes ring fission in the presence of two equivalents of a primary base in a solvent to form a di-carbamate of a substituted cystine diamide of general formula II. Reaction of I with glycine ethyl ester leads to the carbamate derivative of L-cystinyl-diglycine ethyl ester (III), which decomposes on warming to give the free tripeptide ester IV. A similar reaction takes place between IV and the $\mathrm{N}$-carboxy anhydride of DL-alanine in the presence of one equivalent of triethylamine, yielding the ethyl ester of the new pentapeptide di-DL-alanylL-cystinyl-diglycine.

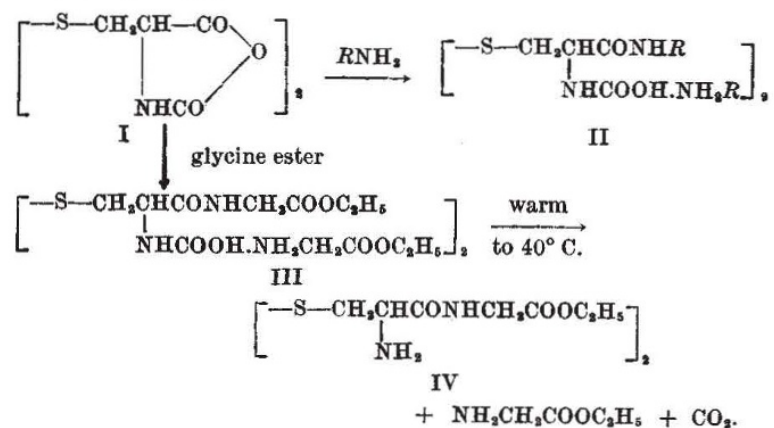

Further, it has been established that the simple $\mathrm{N}$-carboxy anhydrides of amino-acids undergo a general reaction with amino-acid esters under anhydrous conditions according to scheme $A$ : $\underset{\mathrm{NHCO}}{R^{\prime} \mathrm{CHCO}} \backslash \mathrm{O}+2 \mathrm{NH}_{3} \mathrm{CH} R^{\prime \prime} \mathrm{COOEt} \longrightarrow \stackrel{R^{\prime} \mathrm{CHCONHCH} R^{\prime \prime C O O E t}}{\mathrm{fHCOONH}}{ }_{3} \mathrm{CH} R^{\prime} \mathrm{COOEt}$ (A)

Unlike the carbamates derived from simple aminoacid esters ${ }^{6}$, those arising from scheme $A$ are stable at room temperature in absence of moisture and are in many cases crystalline.

Reaction of $\mathrm{N}$-carboxy anhydrides with one equivalent each of amino-acid ester and a tertiary base at $0^{\circ} \mathrm{C}$. or below proceeds according to scheme $B$ :

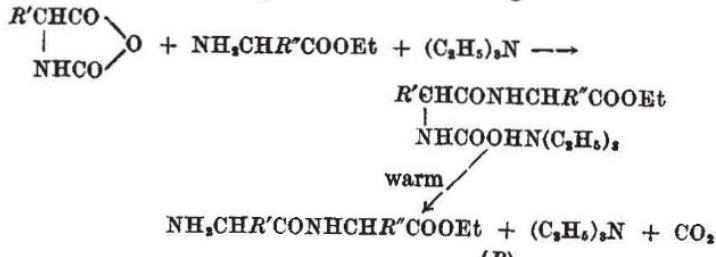

(B)

The carbamates containing a tertiary base decompose slowly at room temperature and rapidly at $30-40^{\circ} \mathrm{C}$., evolving carbon dioxide and leaving the tertiary base and the newly formed peptide ester. They are very deliquescent and are usually obtained as semicrystalline or amorphous powders.

Confirmation of the structure assigned to the inter. mediate carbamates has been obtained by reaction with diazomethane to produce crystalline $\mathrm{N}$-carbomethoxy peptides. Thus, from the new $\mathrm{N}$-carboxy O-acetyl L-tyrosine anhydride, m.p. $99-100^{\circ} \mathrm{C}$., $\mathrm{N}$-carbomethoxy $\mathrm{O}$-acetyl-tyrosyl-glycine ethyl ester is obtained as needles, m.p. $145-146^{\circ} \mathrm{C}$. (found : $\mathrm{C}, 55.7 ; \mathrm{H}, 6 \cdot 0 ; \mathrm{N}, 7 \cdot 7 ; \mathrm{C}_{17} \mathrm{H}_{22} \mathrm{O}_{7} \mathrm{~N}_{2}$ requires C, $55.57 ; \mathrm{H}, 6 \cdot 01 ; \mathrm{N}, 7 \cdot 65$ per cent).

The above schemes provide a new peptide synthesis of wide scope. The N-carboxy anhydrides can be obtained in a high state of purity and in many cases peptide formation can be accomplished by alternate warming and cooling after each addition of reagent. The following peptides have been synthesized in good yield by this method :

DL-Alanyl-glycine L-Tyrosyl-glycine L-Tyrosyl-t-tyrosine DL-Alanyl-DL-alanylglycine

DL-Alanyl-glycylglycine

DL-Dialanyl-Lcystinyl-diglycine

DL-Alanyl-L-tyrosyl-glycine DL-Alanyl-L-tyrosyl-glycylglycine

DL-Alanyl-DL-alanyl-L-tyrosyl. glycyl-glycine

L-Tyrosyl-L-tyrosyl-Ltyrosine

L-Cystinyl-diglycine

I am indebted to the directors of Wolsey, Ltd., for permission to publish this communication.

Research Laboratory, J. LeggetT Batley Wolsey, Ltd., Leicester. June 23.

'Sir Ian Heilbron's presidential address to the Chemical Society March 1949.

${ }^{2}$ Woodward, R. B., and Schramm, C. H., J. Amer. Chem. Soc., 69, 1551 (1947).

${ }^{3}$ Astbury, W. T., and Dalgliesh, C. E., Nature, 162, 596 (1948).

4 Ambrose, E. J., and Hanby, W. E., Nature, 163, 483 (1949).

Brown, C. J., and Coleman, D., Nature, 168, 834 (1949).

'Frankel, M., and Katchalski, E., J. Amer. Chem. Soc., 65, 1670 (1943).

\section{Serum Tryptophane-Perchloric Acid Reaction as a Measure of Tissue Destruction}

SEIBERT and her colleagues ${ }^{1}$, and other workers, found that the polysaccharide content of serum rises above the normal in certain pathological conditions, including tuberculosis and carcinoma, and it was suggested ${ }^{x}$ that this increase is associated with tissue destruction. In view of the possibility that the carbohydrate was derived from nucleic acid, Seibert et al. ${ }^{2}$ applied to serum the tryptophane-perchloric acid reaction of Cohen ${ }^{3}$, when they found a significant increase in the reaction in cases of tuberculosis and several types of carcinoma. The nature of the reacting substance is unknown; but Seibert et al. have produced evidence suggesting that it is derived from proteins. Presumably an increased reaction may also be regarded as being associated with tissue destruction.

It seemed of interest to test this hypothesis by applying the tryptophane-perchloric acid reaction to serum obtained from burned patients, in whom tissue destruction is known to occur, and where possible correlating the results with the excretion of nitrogenous substances. Serial determinations made in six burn cases clearly indicated a pronounced rise in the reacting substance, which reached a maximum usually several days after the burn and generally returned only slowly to a normal level. The most severe burns gave the highest values. 